\title{
Parvovirus B19 infections in state of Rio de Janeiro, Brasil: 526 sera analyzed by IgM-enzyme-linked immunosorbent assay and polymerase chain reaction
}

\author{
MCL Mendonça, SB Ribeiro, JNSS Couceiro+, MG von Hubinger
}

\author{
Departamento de Virologia, Instituto de Microbiologia Prof. Paulo de Góes, Universidade Federal do Rio de Janeiro, \\ 21941-590 Rio de Janeiro, RJ, Brasil
}

In this study were analyzed 526 sera; the patients aged from two days to 65 years old presenting exanthema, which was the most frequent symptom observed, besides fever, adenomegaly, and arthralgia. These sera were negative by enzyme-linked immunosorbent assay (IgM-ELISA) for either rubella (495), toxoplasma (41), cytomegalovirus (12), measles (40), dengue (56), and they were submitted to nested polymerase chain reaction (PCR) for B19 DNA and commercial IgM-ELISA for B19. In 39 abortion cases, IgM or DNA were not detected, therefore they were not took into account for analysis. Specific DNA and IgM were detected respectively in 71 (14.5\%) and IgM in 62 (12.7\%) sera from 487 sera analyzed. IgM and DNA were simultaneously detected in 43 (8.8\%), while agreement among the results by PCR and IgM-ELISA was observed in 440 (90.4\%). The sera were collected from January 1999 to December 2000, most of them in 1999 (325), during winter and spring. The major number of clinical cases was observed in the age group from one to ten years old. IgM or DNA were detected in 23 from 51 municipal districts of the state of Rio de Janeiro, where the samples were collected.

Key words: parvovirus B19 - diagnosis - enzyme-linked immunosorbent assay - polymerase chain reaction - Brazil

The structure of the parvovirus B19 is composed by a protein mixture of VP1 and VP2, which encapsidates a single-stranded DNA molecule. VP2 is the major structural protein in most parvoviruses that comprises about $90 \%$ of the capsid, which is commonly used as tool for diagnosis purposes (Muzyczka \& Berns 2001). This virus was observed for the first time by Cossart et al. (1975). It causes a wide range of human diseases, including erythema infectiosum or fifth disease, which can be confused with rubella or other exanthematic diseases, arthropaties in adults, severe anemia, transient aplastic crisis, hydrops fetalis, and abortion (Feder \& Anderson 1989, Kirchner 1994, Weir 2005). The B19 infections were observed to affect usually children in all the world. This previous experience was demonstrated by presence of seropositivity for anti-B19 IgG from 63\% (Searle et al. 1997) to $80 \%$ (Cassinotti et al. 1997) in adults.

In September 1987, presence of B19 infections was firstly diagnosed in Brazil when parvovirus-like particles were detected in urine of patients during a Brazilian erythema infectiosum outbreak (Takimoto et al. 1988). B19 antigen was also detected in the plasma of a healthy blood donor in Rio de Janeiro (Cruz et al. 1989). Besides, an IgG antibody prevalence of $35 \%$ was demonstrated for children under five years, while almost $80 \%$ was reported in

Finnancial support: CNPq, Faperj, Fundação Universitária José Bonifácio/UFRJ

${ }^{+}$Corresponding author and CNPq Senior Investigator. E-mail: jncouceiro@micro.ufrj.br

Received 6 June 2005

Accepted 23 November 2005 children aged from 11 to 15 years and $90 \%$ in individuals over 50 years old (Nascimento et al. 1990).

In North Brazil, prevalence of specific IgG from 26.2 to $42.6 \%$ was already revealed in population of Belém (Freitas et al. 1990, 1993). In South Brazil, an outbreak of exanthematic diseases was reported during 1998 with $58.3 \%$ of anti-B19 IgM (Lopes et al. 1998) by enzymelinked immunosorbent assay (ELISA). In state of Rio de Janeiro, 9.3\% of positivity for presence of B19 DNA was already observed by nested polymerase chain reaction (nested PCR) methodology from 1996 to 1997, in patients exhibiting previous episodes of exanthematic disease, adenomegaly, fever or spontaneous abortion (Wermelinger et al. 2002). Positivities from 17 to $23 \%$ for B 19 DNA by polymerase chain reaction (PCR) were also observed in sera of patients suspected of parvovirus B19 infection (Sevall 1990, Cassinotti et al. 1993) and patients with arthritis of unknown origin (Cassinotti et al. 1998). After the introduction of measles and rubella vaccination, the differential diagnosis of rash has been specially recommended, since $17.6 \%$ of the exanthema cases after measles vaccination were due to be caused by parvovirus B19 infection, in São Paulo, Brazil (Oliveira et al. 2002b).

To reinforce the importance to include parvovirus B19 diagnosis as routine in public health laboratories this study was developed. Sera collected from symptomatic patients (state of Rio de Janeiro, Brazil) were analyzed by commercial IgM-ELISA and nested PCR, using VP2 antigen or primers mapping to VP2, respectively.

\section{MATERIALS AND METHODS}

Clinical specimens - 526 unique serum samples were provided by the Department of Virology of the Central Laboratory of Public Health (LCNN), which is part of the Secretary of Health of Rio de Janeiro State. The sera were 
negative by IgM-ELISA for either rubella (495), toxoplasma (41), cytomegalovirus (12), measles (40), and dengue (56). The samples were collected between January 1999 and December 2000 from 201 males and 325 females, their ages varying from two days to 65 years. The patients exhibited exanthema as the most frequent symptom, besides fever, adenomegaly, arthralgia, myalgia, itch, headache, abortion, and other ones.

Amplification by nested PCR - B19 DNA was recovered from serum according to the method described by Cassinotti et al. (1993), PCR amplifications was carried out with two consecutive rounds of 35 cycles in an 2400 thermocycler (Perkin-Elmer, Norwalk, CT). In the first round, each cycle consisted of a denaturation step at $94^{\circ} \mathrm{C}$ for $1 \mathrm{~min}$, followed by an annealing step at $50^{\circ} \mathrm{C}$ for $2 \mathrm{~min}$. In the second round, the annealing temperature was changed from $50^{\circ} \mathrm{C}$ to $60^{\circ} \mathrm{C}$ for $2 \mathrm{~min}$, final extension steps at $72^{\circ} \mathrm{C}$ for $7 \mathrm{~min}$ followed both rounds. Since primer extension occurred during the heating from annealing to denaturation temperature, a specific elongation step was omitted in the program. P1 (nucleotides 3954-3971) and P2 (nucleotides 4135-4154) constituted the outer primer pair, and P3 (nucleotides 3997-4016) and P4 (nucleotides 40994117) constituted the inner primer pair, which mapped to a fragment of the major capsid protein VP2 gene (GeneBank NC_000883).

Detection of amplified B19 sequences - The amplified DNA fragments were analyzed by electrophoresis in a $2 \%$ agarose gel stained with ethidium bromide. Fetal calf serum was used as negative control in order to check for possible contamination along with the specimens.

ELISA - Anti-B19 IgM antibodies in sera were tested by commercial ELISA kit, using recombinant capsid protein VP2 as antigen (Biotrin International Ltd.).

Negative control group - Twenty sera from individuals between 17 and 60 years old who did not present any symptoms compatible to an acute parvovirus B19 infection were used as negative controls.

\section{RESULTS}

In this study, 526 serum samples were analyzed by ELISA and PCR. Among these samples, IgM or DNA were not detected from 39 cases of abortion, therefore they were not took into account for analysis. Anti-parvovirus B19 IgM or parvovirus B19 DNA or both were detected in $90(18.5 \%)$ from 487 serum samples when they were analysed by ELISA and PCR. In these sera, DNA was detected in $71(14.5 \%)$ sera and IgM was recorded in 62 (12.7\%). Specific IgM and DNA were simultaneously detected in $43(8.8 \%)$ sera, while sole IgM and sole DNA were detected respectively in $19(3.9 \%)$ and $28(5.7 \%)$ of them. B19 DNA or anti-B19 IgM were not detected in 397 (81.6\%). Agreement among the results by PCR and IgMELISA was observed in 440 (90.4\%) from the total number of sera analyzed here (Table I).

Exanthema was the most frequent symptom exhibited in the clinical cases from which sera were collected, it was observed in $60(96.8 \%)$ from 62 cases with positive results for anti-B19 IgM and 67 (94.4\%) from 71 cases showing positivity for B19 DNA. Fever was observed in 24 (38.7\%) cases with positivity for IgM and $24(33.8 \%)$ cases showing positivity for DNA, adenomegaly in $16(25.8 \%)$ for IgM and $23(32.3 \%)$ for DNA, arthropathy in $7(11.3 \%)$ for IgM and 7 (9.9\%) for DNA, itch in $4(6.5 \%)$ for IgM and 8 (11.3\%) for DNA, as shown in Table II.

In the age group from one to ten years, where the major number of clinical cases was observed, anti-B19 IgM was detected in $38(18.4 \%)$ and B19 DNA in 36 (17.5\%) from 206 serum samples (Table III). The same Table also shows a higher number of tested sera in females (286 cases) than in males (201 cases). In males, anti-B19 IgM and B19

TABLE I

Results for IgM and DNA detection in sera analyzed by enzyme-linked immunosorbend assay and polymerase chain reaction

\begin{tabular}{llcr}
\hline & & \multicolumn{2}{c}{ Sera analyzed } \\
\cline { 3 - 4 } IgM & DNA & Number & $\%$ \\
\hline Positive & Positive & 43 & 8.8 \\
Negative & Positive & 28 & 5.7 \\
Positive & Negative & 19 & 3.9 \\
Negative & Negative & 397 & 81.6 \\
\hline Total & & 487 & 100.0 \\
\hline
\end{tabular}

TABLE II

Symptoms observed in patients analyzed for presence of IgM and DNA in sera

\begin{tabular}{|c|c|c|c|c|c|c|c|}
\hline Symptoms & IgM+ DNA+ & IgM+ DNA- & IgM- DNA+ & IgM- DNA- & IgM+ & DNA + & Total \\
\hline Exanthema & 41 & 19 & 26 & 353 & 60 & 67 & 439 \\
\hline Fever & 15 & 9 & 9 & 199 & 24 & 24 & 232 \\
\hline Adenomegaly & 14 & 2 & 9 & 111 & 16 & 23 & 136 \\
\hline Arthropathy & 5 & 2 & 2 & 23 & 7 & 7 & 32 \\
\hline Itch & 3 & 1 & 5 & 40 & 4 & 8 & 49 \\
\hline Myalgia & 0 & 0 & 4 & 10 & 0 & 4 & 14 \\
\hline Headache & 0 & 0 & 2 & 24 & 0 & 2 & 26 \\
\hline Retrorbital pain & 1 & 0 & 1 & 8 & 1 & 2 & 10 \\
\hline Cough & 1 & 1 & 0 & 13 & 2 & 1 & 15 \\
\hline Coryza & 1 & 1 & 1 & 19 & 2 & 2 & 22 \\
\hline Tonsillitis & 1 & 0 & 1 & 9 & 1 & 2 & 10 \\
\hline Conjunctivitis & 1 & 0 & 0 & 3 & 1 & 1 & 4 \\
\hline
\end{tabular}


TABLE III

Distribution of results for IgM and DNA detection in groups classified by age and sex

\begin{tabular}{|c|c|c|c|c|c|c|c|c|c|c|c|c|c|c|c|c|c|c|}
\hline \multirow[b]{2}{*}{ Age (years) } & \multicolumn{3}{|c|}{$\mathrm{IgM}+\mathrm{DNA}+$} & \multicolumn{3}{|c|}{ IgM- DNA+ } & \multicolumn{3}{|c|}{ IgM+ DNA- } & \multicolumn{3}{|c|}{ IgM+ } & \multicolumn{3}{|c|}{ DNA+ } & \multicolumn{3}{|c|}{ Total } \\
\hline & M & $\mathrm{F}$ & $\mathrm{T}$ & M & $\mathrm{F}$ & $\mathrm{T}$ & M & $\mathrm{F}$ & $\mathrm{T}$ & M & $\mathrm{F}$ & $\mathrm{T}$ & M & $\mathrm{F}$ & $\mathrm{T}$ & M & $\mathrm{F}$ & $\mathrm{T}$ \\
\hline$<01$ & 1 & 0 & 1 & 2 & 0 & 2 & 1 & 0 & 1 & 2 & 0 & 2 & 3 & 0 & 3 & 36 & 32 & 68 \\
\hline $01-10$ & 12 & 11 & 23 & 8 & 5 & 13 & 5 & 10 & 15 & 17 & 21 & 38 & 20 & 16 & 36 & 106 & 100 & 206 \\
\hline $11-20$ & 4 & 4 & 8 & 2 & 4 & 6 & 0 & 1 & 1 & 4 & 5 & 9 & 6 & 8 & 14 & 31 & 49 & 80 \\
\hline $21-30$ & 0 & 7 & 7 & 0 & 3 & 3 & 1 & 1 & 2 & 1 & 8 & 9 & 0 & 10 & 10 & 8 & 41 & 49 \\
\hline $31-40$ & 0 & 2 & 2 & 1 & 0 & 1 & 0 & 0 & 0 & 0 & 2 & 2 & 1 & 2 & 3 & 8 & 25 & 33 \\
\hline $41-50$ & 0 & 2 & 2 & 0 & 1 & 1 & 0 & 0 & 0 & 0 & 2 & 2 & 0 & 3 & 3 & 4 & 20 & 24 \\
\hline$>50$ & 0 & 0 & 0 & 0 & 0 & 0 & 0 & 0 & 0 & 0 & 0 & 0 & 0 & 0 & 0 & 2 & 7 & 9 \\
\hline WI & 0 & 0 & 0 & 0 & 2 & 2 & 0 & 0 & 0 & 0 & 0 & 0 & 0 & 2 & 2 & 6 & 12 & 18 \\
\hline Total & 17 & 26 & 43 & 13 & 15 & 28 & 7 & 12 & 19 & 24 & 38 & 62 & 30 & 41 & 71 & 201 & 286 & 487 \\
\hline
\end{tabular}

M: male ; F: female ; T: total ; WI: without information

DNA were detected in $24(11.9 \%)$ and $30(14.9 \%)$ sera respectively, while the detection in females occurred in 38 $(13.3 \%)$ and $41(14.3 \%)$ sera for IgM and DNA respectively. The frequency of specific IgM and DNA did not show significative difference among males and females.

The monthly distribution of analyzed sera is observed in Fig. 1 that reveals detection of anti-B19 IgM in 50 (15.4\%) and B19 DNA in 59 (18.6\%) from 325 serum samples collected in 1999. In analysis of samples collected in 2000, anti-B19 IgM was detected in 12 (7.4\%) and B19 DNA was also detected in 12 samples from 162 .

Anti-B19 IgM or B19 DNA were detected in serum samples collected in 23 from 51 municipal districts of the state of Rio de Janeiro (Fig. 2), analyzed here : Angra dos Reis, Barra do Piraí, Barra Mansa, Piraí, Resende, and Volta Redonda in south region of the state (14 sera, 9 for IgM and 11 for DNA); Itaperuna and Santo Antônio de Pádua in northwest region (2 sera, for IgM and DNA); Araruama,
Armação de Búzios, Cabo Frio, Casemiro de Abreu, and Rio das Ostras in lowlands region (15 sera, 10 for IgM and 14 for DNA); Duque de Caxias, Japeri, Niterói, Nova Iguaçu, Paty do Alferes, Rio de Janeiro, São Gonçalo, and São João de Meriti in metropolitan region (56 sera, 38 for IgM and 44 for DNA); Paraíba do Sul and Três Rios in central region (all 2 sera for $\operatorname{IgM}$ ).

\section{DISCUSSION}

In this study, $12.7 \%$ of positive results were observed when sera were analyzed by IgM-ELISA, as already presented in other studies on exanthematic diaseases. In Brazil, state of Rio de Janeiro, the presence of IgM for these viruses has already been demonstrated for $13.6 \%$ of the sera collected from patients exhibiting previous episodes of exanthematic disease, adenomegaly, fever or spontaneous abortion (Wermelinger et al. 2002). In Niteroi (state of Rio de Janeiro), presence of IgM specific for parvovirus

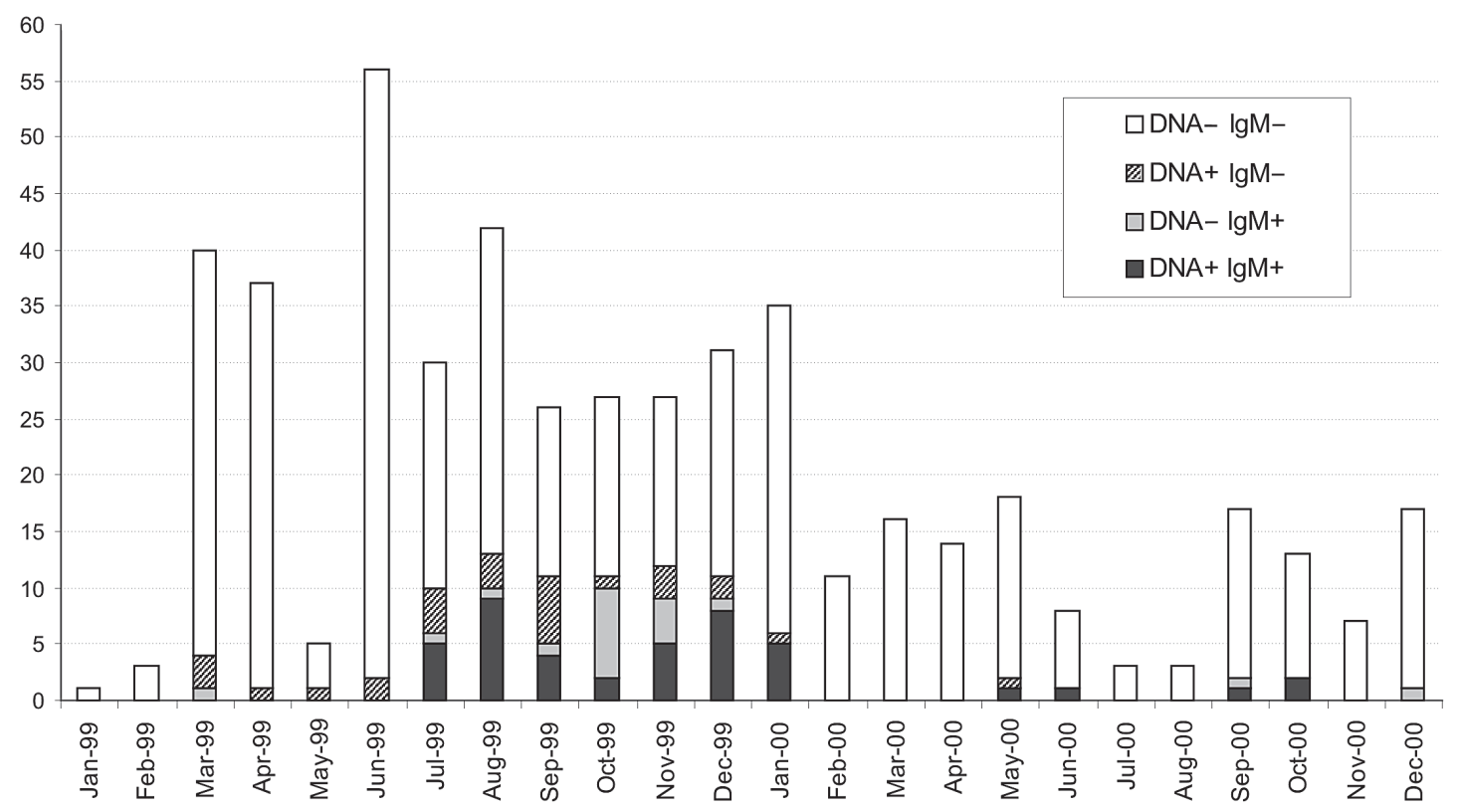

Fig. 1: monthly distribution of results for IgM and DNA detection in sera collected from January 1999 to December 2000. 


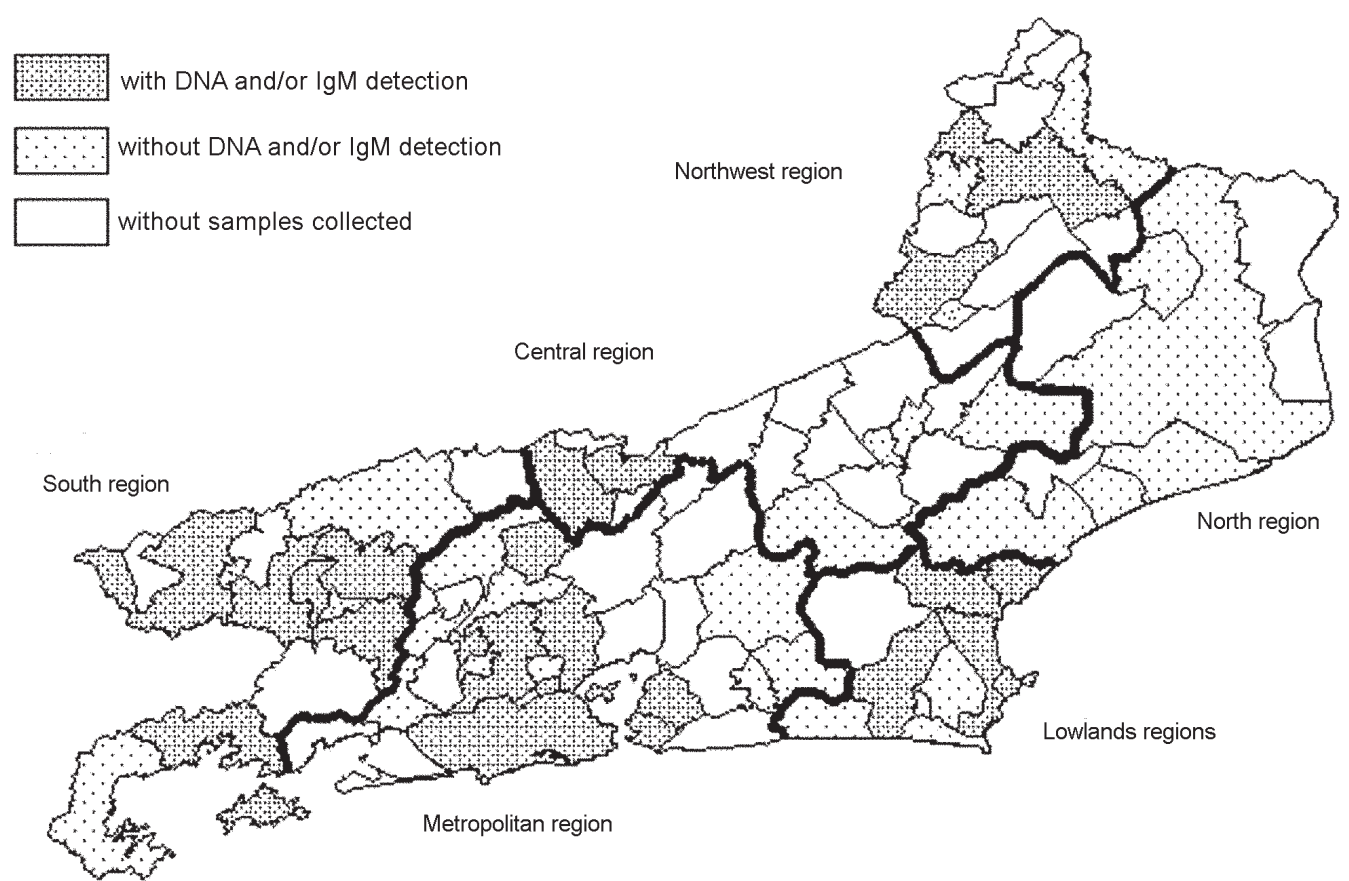

Fig. 2: geographical distribution of results for IgM or DNA detection in sera collected in different municipal districts of the state of Rio de Janeiro.

B19 was demonstrated in $9.2 \%$ of the sera collected from patients presenting exanthematic syndromes (Oliveira et al. 2001). The detection of 27 positive sera for specific IgM in the states of Rio de Janeiro and Espírito Santo was reported between 1992 and 1994 (Cubel et al. 1996b). In Niteroi, from 1994 to 1999, IgM for parvovirus B19 was identified in $31.8 \%$ of the sera (105) by Oliveira et al. (2002a). Positivity of $39.8 \%$ for anti-B19 IgM had already been shown by Cassinotti et al. (1993). Different factors as the methodology used for analysis, the year-to-year variation, the seasonality and the presence of higher percentuals of other exanthematic diseases can explain the different rates of positive results.

In our study, B19 DNA was detected in $14.5 \%$ of the analyzed samples, when using nested PCR methodology, higher than the percentual that had already been observed (9.3\%) in sera collected in Rio de Janeiro from 1996 to 1997 by Wermelinger et al. (2002). Percentuals of 17, 23, and $20 \%$ for B 19 DNA respectively were already reported in patients with symptoms of parvovirus B19 infection by Sevall (1990) and Cassinotti et al. (1993, 1997).

The analysis of 23 cases of non immune fetal hydropsy by in situ hibridisation, dot blot hibridisation or PCR permitted to detect six positive cases of B19 infection, which occurred in 1974, 1980, 1982, 1987 and 1988 (Cubel et al. 1996a). From 1998 to 1999, 1,303 viremic blood donors were tested by gel hemagglutination. Nine plasma showing positive or indeterminate results were analyzed by dot-blot, only the strongly positive by gel hemagglutination was confirmed by dot-blot (Setúbal et al 2004).

In Belém, state of Pará, it was demonstrated IgM, IgG and PCR positivity for infection by B19 in $47.7 \%$ of individuals presenting arthropaty (Freitas et al. 2002). In pa- tients suffering non-A-E hepatitis, B19 infection was confirmed by IgM-ELISA in 2.3\% (Pinho et al. 2001). Exhantema B19 infection was confirmed by IgM-ELISA and PCR for $17.6 \%$ of the individuals after post measles vaccination (Oliveira et al. 2002b).

From January to May of 2001, multiple cases of erythema infectiosum were observed in a school in Limburg (Netherlands) by Hoebe et al. (2002). In this outbreak, $\mathrm{IgM}$ for parvovirus B19 was revealed in $65 \%(15 / 23)$ of the tested sera, while B19 DNA was demonstrated in $70 \%$ $(16 / 23)$ of the sera analysed by PCR. During an exanthematic outbreak in a school located in a Buenos Aires province (Argentina), affecting 21 individuals out of 1,400, Alonso et al. (2003) were able to detect anti-B19 $\operatorname{IgM}$ in $90.8 \%$ and parvovirus B19 DNA in $66.7 \%$ of 21 sera.

In 28 cases of DNA detection in ausence of IgM studied here, one case exhibited only arthralgia, one presented coryza, itch and adenomegaly while exanthema was presented in 26 cases, with or without additional symptoms. In those 28 cases, $25 \%$ of the samples had been collected from 1 to 4 days after onset of the clinical symptoms, $7 \%$ after 15 days, while in $68 \%$ this information was not available. One of the cases, presenting fever, exanthema and arthralgia, exhibited initially both IgM and DNA and sole B19 DNA 34 days afterwards, when arthralgia remained as unique symptom.

The role of B19 as ethiological agent can not be confirmed for those 28 cases where was detected only DNA. In these patients, the infections were possibly in acute phase before IgM response, or exhibited a DNA persistence after disappearance of IgM. Other authors observed similar data, thus Cassinotti et al. (1993) observed posi- 
tive results for B19 DNA and negative results for specific $\operatorname{IgM}$ in $6 \%$ of the cases, when analyzing 200 patients with suspected B19 infection. Gallinella et al. (2003), when analysing 344 suspected cases of B19 infection occurred during an outbreak, verified the presence of only DNA in 50 cases, both DNA and IgM in 49 cases and only IgM in 26 cases, showing that the detection of DNA in ausence of $\operatorname{IgM}$ is not uncommon during epidemics. Otherwise, the presence of B19 DNA at low level was already detected until one year after the clinical symptoms in an immunocompetent patient (Cassinotti \& Siegl 2000). Besides, Candotti et al. (2004) were able to detect B19 DNA in $0.9,1.3,0.55$, and $1.25 \%$ in United Kingdom, Ghana, South Africa, and Malawi, respectively, when analyzing the virus persistence in blood donors. In these DNA positive blood samples, negative detection for IgM was observed in United Kingdom and Ghana for 89\% (8/9) and $77 \%(10 / 13)$ of the cases respectively.

In our analysis, the patients presenting anti-B19 $\operatorname{IgM}$ or B19 DNA exhibited mainly exanthema, fever, adenomegaly, and itch as symptoms. The sera of 39 women that suffered abortion exhibited negative results when analyzed by IgM-ELISA and PCR for presence of parvovirus B19 infections, however Wermelinger et al. (2002) observed positive results in $11 \%$ of the cases of abortion.

Exanthema was the most frequent symptom for the total number of patients analyzed and it also was the most commonly observed in the positive cases for detection of anti-B19 IgM and B19 DNA. The infection by B19 viruses is not usually distinguished from rubella, measles, and other exanthematic diseases, therefore the sera tested here were collected from patients with suspect of these diseases.

Children aged from one to ten years was the major group studied here, which has already been shown in other studies. A great number of positive sera of B19 infection has already been observed, when analyzing children from five to nine years of age (Oliveira et al. 1996). In samples collected in a blood bank, significative anti-B19 IgG levels were already demonstrated for $35 \%$ of children under five years old, $80 \%$ of individuals between 11 and 15 years and $90 \%$ of those older than 50 years old, between 1985 and 1986. A lower prevalence during the childhood was revealed, a progressively higher number of individuals showing to be infected by the viruses (Nascimento et al. 1990). Similar results were observed in England and Wales, where the prevalence of anti-B19 IgG increased with age, $5-15 \%$ in children $1-5$ years, rising from $50-60 \%$ in young adults to more than $85 \%$ in those over 70 years old (Cohen \& Buckley 1988).

In our analysis, the higher levels of detection of antiB19 IgM and B19 DNA were observed from July to December (winter and spring), which was already observed before by other authors (Cubel et al. 1996b, Wermelinger et al. 2002). However, the percentuals of detection of IgM and DNA were significatively higher in 1999 than in 2000.

In the present study, the presence of DNA or IgM for B19 in 23 municipal districts revealed their wide distribution in the state of Rio de Janeiro as already demonstrated by Wermelinger et al (2002) in ten districts.
The results reinforce the relevance of the parvovirus B19 as infectious agent responsible for children exhantematic diseases and thus the importance to include B19 diagnosis as routine in public health laboratories.

\section{ACKNOWLEDGMENT}

To the staff of the Department of Virology of the Public Health Central Laboratory for the sera samples and the Institute of Virology of the Vienna University, Austria, for material and technical assistance. To Rosa de Fátima Costa Ferreira da Silva for expert technical assistance throughout the study.

\section{REFERENCES}

Alonso A, Distefano A, Carlino O, Polito A 2003. Exanthematous outbreak caused by human parvovirus B19 school in Banderalo, Argentina. Rev Argent Microbiol 35: 171-174.

Candotti D, Etiz N, Parsyan A, Allain JP 2004. Identification and characterization of persistent human erythrovirus infection in blood donor samples. J Virol 78: 12169-12178.

Cassinotti P, Siegl G 2000. Quantitative evidence for persistence of human parvovirus B19 DNA in an immunocompetent individual. Eur J Clin Microbiol Infect Dis 19: 886895.

Cassinotti P, Burtonboy G, Fopp M, Siegl G 1997. Evidence for persistence of human parvovirus B19 DNA in bone marrow. J Med Virol 53: 229-232.

Cassinotti P, Siegl G, Michel BA, Brühlmann P 1998. Presence and significance of human parvovirus B19 DNA in synovial membranes and bone marrow from patients with arthritis of unknown origin. J Med Virol 56: 199-204.

Cassinotti P, Weitz M, Siegl G 1993. Human parvovirus B19 infections: routine diagnosis by a new nested polymerase chain reaction assay. J Med Virol 40: 228-234.

Cohen BJ, Buckley MM 1988. The prevalence of antibody to human parvovirus B19 in England and Wales. J Med Microbiol 25: 151-153.

Cossart YE, Field AM, Cant B, Widdows D 1975. Parvoviruslike particles in human sera. Lancet 1: 72-73.

Cruz AS, Serpa MJA, Barth OM, Nascimento JP 1989. Detection of the human parvovirus B19 in a blood donor plasma in Rio de Janeiro. Mem Inst Oswaldo Cruz 84: 279-280.

Cubel RCN, Garcia AG, Pegado CS, Ramos HI, Fonseca ME, Clewley JP, Cohen BJ, Nascimento, JP 1996a. Human parvovirus B19 infection and hydrops fetalis in Rio de Janeiro. Mem Inst Oswaldo Cruz 91: 147-151.

Cubel RCN, Siqueira MM, Santos EO, Pires MF, Cruz CMF, Nascimento JP 1996b. Human parvovirus B19 infections among exanthematic diseases notified as measles. Rev Soc Bras Med Trop 30: 15-20.

Feder Jr HM, Anderson I 1989. Fifth disease: a brief review of infections in childhood, in adulthood and in pregnancy. Arch Intern Med 149: 2176-2179.

Freitas RB, Miranda MFR, Shirley J, Tudor R, Desselberger U, Linhares AC 1993: Parvovirus B19 antibodies in sera of patients with unexplained exanthemata from Belém, Pará, Brazil. Mem Inst Oswaldo Cruz 88: 497-499.

Freitas RB, Monteiro TA, Silva Filho MG, Linhares AC. 2002. Association between human parvovirus B19 and arthropathy in Belém, Pará, North Brazil. Rev Inst Med Trop São Paulo 44: 17-22. 
Freitas RB, Wong D, Boswell F, Miranda MFR, Linhares AC, Shirley J, Desselberger U 1990. Prevalence of human parvovirus B19 and rubellavirus infections in urban and remote rural areas in northern Brazil. J Med Virol 32: 203-208.

Gallinella G, Zuffi E, Gentilomi G, Manaresi E, Venturoli S, Bonvicini F, Cricca M, Zerbini M, Musiani M 2003. Relevance of B19 markers in serum samples for diagnosis of parvovirus B19-correlated diseases. J Med Virol 71: 135139.

Hoebe CJ, Claas EC, Steenbergen JE, Kroes AC 2002. Confirmation of an outbreak of parvovirus B19 in a primary school using IgM ELISA and PCR on thumb prick blood samples. J Clin Virol 25: 303-307.

Kirchner JT 1994. Erythema infectiosum and other parvovirus B19 infections. Am Farm Phys 50: 335-342.

Lopes DP, Paula WNS, Aguiar FS, Oliveira SA, Siqueira MS, Cubel RCN, Garcia AGP, Nascimento JP 1998. Human Parvovirus B19: exanthematic diseases diagnosis. Virus Rev Res 3: 126.

Muzyczka N, Berns KI. 2001. Parvoviridae: the viruses and their replication. In DM Griffin, RA Lamb, MA Martin, B Roizman, SE Straus (eds), Fields Virology, Vol. 2. Lippincott Williams \& Wilkins, Philadelphia, p. 2327-2359.

Nascimento JP, Buckley MM, Brown KE, Cohen BJ 1990. The prevalence of antibody to human parvovirus B19 in Rio de Janeiro, Brazil. Rev Inst Med Trop São Paulo 32: 41-45.

Oliveira SA, Brandão AB, Fernandes DG, Bettini LR, Carvalho AB, Pereira ACM, Azevedo KM, Nascimento JP 1996. Human Parvovirus B19 infection: clinical and epidemiological study of 24 cases. Rev Inst Med Trop São Paulo 38: 323-327.

Oliveira SA, Camacho LAB, Pereira ACM, Faillace TF, Setúbal S, Nascimento JP 2002a. Clinical and epidemiological aspects of human parvovirus B19 infection in an urban area in Brazil (Niteroi city area, State of Rio de Janeiro, Brazil).
Mem Inst Oswaldo Cruz 97: 965-970.

Oliveira MI, Curti SP, Figueiredo CA, Afonso AMS, Theobaldo M, Azevedo RS, Durigon EL 2002b. Rash after measles vaccination: laboratory analysis of sera reported in São Paulo, Brazil. Rev Saúde Públ 36: 155-159.

Oliveira SA, Siqueira MM, Camacho LAB, Nogueira RM, Spinetti CC, Cubel RCN, Knowles W, Brown DW 2001. The aetiology of maculopapular rash diseases in Niterói, State of Rio de Janeiro, Brazil: implications for measles surveillance. Epidemiol Infect 127: 509-516.

Pinho JRR, Alves VAF, Vieira AF, Moralez MOS, Fonseca LEP, Guz B, Wakamatsu A, Cançado ELR, Carrilho FJ, Silva LC, Bernardini AP, Durigon EL 2001. Detection of human parvovirus B19 in a patient with hepatitis. Braz J Med Biol Res 34: 1131-1138.

Searle K, Guillliard C, Enders G 1997. Parvovirus B19 diagnosis in pregnant women-quantification of IgG antibody levels $(\mathrm{IU} / \mathrm{mL})$ with reference to the international parvovirus standard serum. Infection 25: 32-34.

Setúbal S, Cárdias CAS, Oliveira AS, Nascimento JP 2004. Viremic blood donor found by a rapid screening method in a season of high human parvovirus B19 activity in Niterói, Rio de Janeiro, Brazil. Mem Inst Oswaldo Cruz 99: 95-99.

Sevall JS 1990. Detection of parvovirus B19 by dot-blot and polymerase chain reaction. Mol Cell Probes 4: 237-246.

Takimoto S, Tanaka H, Waldman EA, Ueda M, Ishida MA, Lacerda AM, Ishimaru T, Paiva TM, Nagamori AH, Souza MCO 1988. Rapid diagnosis of parvovirus infection in patients with erythema infectious, Abst IV Cong Bras Virol, São Lourenço, p. 109.

Weir E 2005. Parvovirus B19 infection: fifth disease and more. Can Med Assoc J 172: 743.

Wermelinger MCMW, Oelemann WMR, Mendonça MCL, Naveca FG, von Hubinger MG 2002. Detection of human parvovirus B19 infection: a study of 212 suspected sera in the state of Rio de Janeiro, Brazil. J Clin Virol 25: 223-230. 